[Agr. Biol. Chem., Vol. 26, No. 9, p. 596 610, 1962]

\title{
Excretion of $5^{\prime}$-Nucleotides by Bacteria*
}

\author{
Part II. Formation of $5^{\prime}$-Nucleotides by Degradation of Endogenous \\ Ribonucleic Acid from Washed Cells of a Bacillus \\ By Kôichi Ogata**, Akira Imada and Yoshio Nakao \\ Research Laboratories, Takeda Chemical Industries, Ltd., Osaka
}

Received June 4, 1962

\begin{abstract}
For the purpose of clarifying the mechanism of extracellular formation of $5^{\prime}$-nucleotides during cultivation of a Bacillus, which had been reported previously ${ }^{1)}$, attempts were made to form 5'-nucleotides by non-proliferating cells of this Bacillus.

It was found that this Bacillus rapidly degrades endogenous RNA and consequently forms $5^{\prime}$-nucleotides extracellularly, when the washed cells are incubated in alkaline salt or buffer solutions.

Comparison of the process of the excretion of $5^{\prime}$-nucleotides from washed cells with that of the accumulation of $5^{\prime}$-nucleotides during cultivation revealed that both were brought about by the same mechanism, i.e., the degradation of endogenous RNA.

Various factors which affect the degradation of endogenous RNA were also examined and the biological significance of this kind of RNA-degradation was discussed.
\end{abstract}

\section{INTRODUCTION}

In the previous paper ${ }^{1)}$, the authors reported that $5^{\prime}$-nucleotides were accumulated in the culture fluid of a Bacillus. Since the accumulation took place in parallel with the reduction of intracellular RNA during the cultivation and since the composition of nucleotides accumulated in the culture fluid resembled that of intracellular RNA, these nucleotides were postulated to be breakdown products of intracellular RNA.

The present work was carried out to substantiate the deduction mentioned above.

\footnotetext{
Abbreviations: RNA, ribonucleic acid; DNA, deoxyribonucleic acid AMP, GMP, GMP and UMP, adenylic, guanylic, cytidylic and uridylic acid; ADP, GDP, CDP and UDP, ribonucleoside 5'-diphosphates of adenine, guanine, cytosine and uracil; PCA, perchloric acid; Tris, tris (hydroxymethyl) aminomethane; EDTA, ethylenediamine tetra-as etic acid.

* Degradation of Nucleic: Acids and their Related Compounds by Microbial Enzymes. Part XIV.

** Present address: Department of Agricultural Chemistry, Kyoto University, Kyoto, Japan.

1) K. Ogata, A. Imada and Y. Nakao, This Journal, 26, 586 (1962).
}

At first, we studied the process of degradation of endogenous RNA and formation of 5 -nucleotides by non-proliferating cells of this Bacillus. Then we showed some evidences that the accumulation of $5^{\prime}$-nucleotides during cultivation is brought about by the same mechanism as the excretion of $5^{\prime}$-nucleotides from non-proliferating cells of this Bacillus.

At the same time, various factors which affect the degradation of endogenous RNA were examined and their effects were discussed.

Biological significance of this kind of excretion was also discussed.

\section{MATERIALS AND METHODS}

\section{Biological Methods.}

Bacterial Strains: Bacillus sp. No. 17-5, a soil bacterium, which has the ability to form 5'-nucleotides in the culture fluid during cultivation was used. Its characteristics were described in the preceding paper ${ }^{1}$. Other strains were obtained from the Institute for 
Fermentation, Osaka.

Cultivation: The procedure for growth experiments was much the same as that reported previously ${ }^{1)}$. Usually peptone-glycerol medium (PG-medium) in which Polypeptone (Daigo Nutritve Chemicals, Ltd., Osaka) was substitued for Casamino acids (Difco, vitamin-free) in G-medium ${ }^{1)}$ was used for the purpose of obtaining log-phase cells. Constituents of the other media are indicated in Results.

\section{Analytical Methods.}

Preparation of Suspensions of Intact and Disrupted Cells. Bacillus sp. No. 17-5 was grown in PG-medium at $28^{\circ} \mathrm{C}$ unless otherwise specified, and the cells were harvested in the later logarithmic phase of growth (12 to 16 hours after inoculatoin) by centrifugation, washed twice with cold distilled water and resuspended in distilled water to give a density of 12.5 to $15 \mathrm{mg}$ dry cells per ml (suspension of intact cells). In some cases this cell suspension was sonicated by a Sakuma $\mathrm{SV}-505$ sonic oscillator at $10 \mathrm{kc}$ for 10 minutes in the cold, and centrifuged at 16,000 r.p.m. in a Kubota $\mathrm{KR}-6 \mathrm{~L}$ centrifuge for 30 minutes at $0^{\circ} \mathrm{C}$. The resulting supernatant fluid (suspension of disrupted cells) contained more than $90 \%$ of the nucleic acids originally present in the suspension of intact cells.

Excretion of $260 \mathrm{~m} \mu$-Absorbing Material. The suspension of intact washed cells was mixed in a centrifuge tube with an equal volume of buffer, and incubated at $37^{\circ} \mathrm{C}$ unless otherwise mentioned. After an adequate period ( 15 to 300 minutes) of incubation, the mixture was cooled by immersing the tube in an ice bath and centrifuged in the cold.

The supernatant fluid thus obtained was designed as "excreted solution".

The rate of excretion was routinely calculated as follows: both the excreted solution and the mixture before incubation of cell suspension and buffer were mixed with an equal volume of $10 \%$ PCA and extracted for 30 minutes at $80^{\circ} \mathrm{C}$. The resulting precipitates were centrifuged off and the absorbance of both supernatants at the wave length of $260 \mathrm{~m}_{\mu}$ were measured with a Hitachi EPU-IIA spectrophotometer. The rate of excretion was calculated from the proportion of the absorbance of the excreted solution to that of the mixture of cell suspension and buffer.

Since among cellular $260 \mathrm{~m}_{\mu}$-absorbing materials, RNA predominated over DNA and acid-soluble compounds to a great extent (see Results), the rate of excretion calculated in this way roughly approximated the degree of degradation of intracellular RNA.

Degradation of Endogenous Nucleic Acids. The suspension of intact or disrupted cells was mixed with buffer and incubated at $37^{\circ} \mathrm{C}$ as described previously, and the reaction was stopped by the addition of cold PCA to give a final concentration of $5 \%$ and centrifuged at $0^{\circ} \mathrm{C}$. This acid supernatant was decantated into a test tube and heated for 30 minutes at $80^{\circ} \mathrm{C}$ and the absorbance at $260 \mathrm{~m} \mu$ was measured $\left(\mathbf{E X}_{260}\right)$. Simultaneously the acid supernatant of the reaction mixture was obtained before incubation and the absorbance was measured just the same as before $\left(\mathbf{E O}_{260}\right)$. The difference of the absorbances between $\mathbf{E X}_{260}$ and $\mathrm{EO}_{260}$ was designated as $\Delta \mathrm{E}_{260}$. Total absorbance of the suspension was also measured as follows: the mixture of suspension of intact or disrupted cells and buffer was mixed with an equal volume of $10 \%$ PCA and heated for 30 minutes at $80^{\circ} \mathrm{C}$, the precipitates were centrifuged off and the absorbance of the supernatant fluid was measured $\left(\mathbf{E T}_{260}\right)$. The degree of the degradation of nucleic acids was calculated using the equation below.

$$
\text { Degree of degradation }(\%)=\frac{\Delta \mathrm{E}_{260}}{\mathrm{ET}_{260}-\mathrm{EO}_{260}} \times 100
$$

Extraction of Acid-soluble Compounds, Lipids and Nucleic Acids and Determination of Nucleic Acids. Schneider's method ${ }^{2)}$ was employed with slight modification. In our experiments, acid-soluble compounds were extracted with cold 5\% PCA for 30,15 and 5 minutes successively in the cold. The extraction of lipids and of nucleic acids was exactly the same as in Schneider's original report. RNA and DNA in the hot acid extract were determined as described in the previous paper ${ }^{1)}$.

Phosphorus Determinations. Orthophosphate, acidlabile phosphate, total phosphate, 5'-nucleotide-phosphate and monoester-phosphate were determined by the same methods as in the previous paper ${ }^{1}$.

Ion-exchange Chromatography. The procedure was the same as reported previously ${ }^{1)}$.

\section{RESULTS}

Degradation of Endogenous RNA and Formation on $5^{\prime}$-Nucleotides

Effects of Various Conditions on the Degradation of Endogenous Nucleic Acids.

Effect of pH. When the suspension of cells

2) W.C. Schneider, J. Biol. Chem., 161, 293 (1945). 
was incubated for a short period in buffers of various $\mathrm{pH}$ values, ultraviolet absorbing materials were rapidly excreted into the suspending media. Their absorption spectra in the ultraviolet region had maxima around $260 \mathrm{~m} \mu$ and minima around $235 \mathrm{~m} \mu$ and they were similar to those of purine-pyrimidine mixtures (Fig. 1).

Degrees of the excretion (\%) were 12.5, $16.3,18.1,49.5,67.3$ and 43.7 at $\mathrm{pH} 4.0,5.0$, $6.0,7.1,8.2$ and 8.9 , respectively, and the excretion occurred optimally in alkaline $\mathrm{pH}$. For more precise optimal $\mathrm{pH}$ determination, the washed cells were incubated in $0.25 \mathrm{M}$ Tris buffer and $0.25 \mathrm{~m}$ glycine- $\mathrm{NaOH}$ buffer between $\mathrm{pH} 7.0$ and 10.5 and the degradation of nucleic acids was measured. As shown in Fig. 2, two $\mathrm{pH}$ optima, around $\mathrm{pH} 8.0$ in Tris buffer and around $\mathrm{pH} 9.8$ in glycine- $\mathrm{NaOH}$ buffer were observed for the degradation of nucleic acids. Although the presence of two apparent $\mathrm{pH}$ optima seemed to be attributed

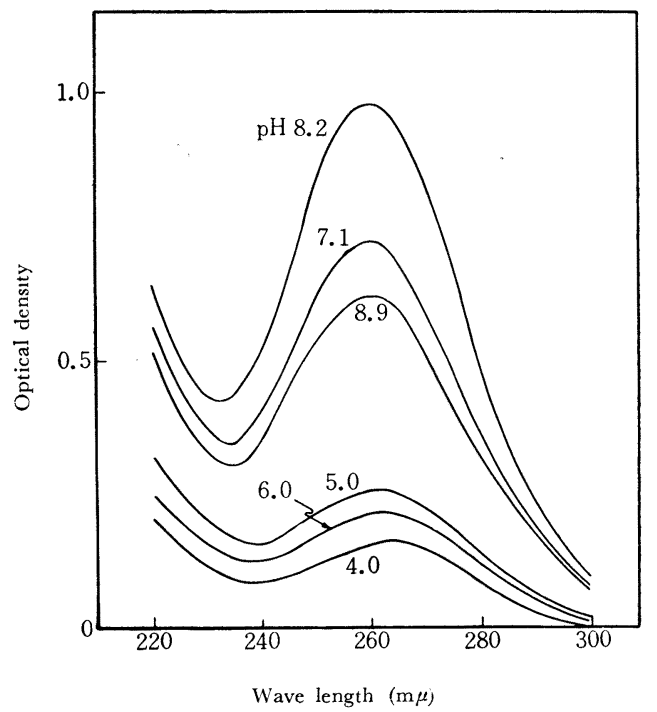

FIG. 1. Ultraviolet Absorption Spectra of the Excreted Solutions.

Washed cells were suspended in $0.25 \mathrm{M}$ acetate buffer of $\mathrm{pH} 4.0$, 5.0 and 6.0 and in $0.25 \mathrm{M}$ Tris buffer of $\mathrm{pH} \mathrm{7.1,8.2} \mathrm{and} 8.9$ and incubated for 30 minutes at $37^{\circ} \mathrm{C}$.

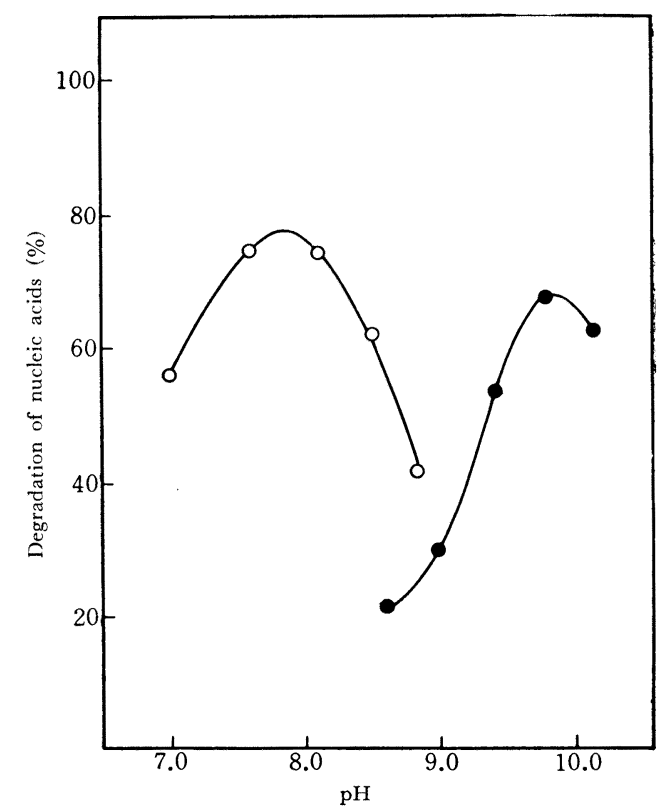

FIG. 2. The Effect of $\mathrm{pH}$ on the Degradation of Intracellular Nucleic Acids.

Washed cells were suspended in buffers as shown and incubated for 40 minutes at $37^{\circ} \mathrm{C}$.

$0.25 \mathrm{M}$ Tris buffer
$0.25 \mathrm{M}$ Glycine-NaOH buffer

to the difference in type of buffers and not to the presence of two routes of degradation, the degradation of nucleic acids in intact cells. was often carried out at both $\mathrm{pH}$ optima.

Effect of Aeration. Washed cells were incubated in 0.25 m glycine-NaOH buffer, $\mathrm{pH} 9.55$ without and with aeration by a Monod's apparatus for shaking culture.

As shown in Table I, the rate of degradation of the intracellular RNA as well as that of the decrease of $260 \mathrm{~m} \mu$ absorbing material from the cells were reduced by the aeration, while the rate of the increase of $260 \mathrm{~m} \mu \mathrm{ab}$ sorbing material in the suspending medium was little affected by the aeration. This consequently resulted in the appearance of considerably larger amount of $260 \mathrm{~m} \mu$ absorbing material in the suspending medium than that disappeared from the cells, and disordered the stoichiometry, that is a coincidation of 
Table I. The Effect of Aeration on the Degradation of RNA AND the ExcReTION OF $260 \mathrm{~m} \mu$ ABSORBING MATERIAL

Incubation
period (hr)

$\begin{array}{lll} & & \text { Aerated } \\ 1 & 67.6 & 49.2 \\ 2 & 80.8 & 69.6 \\ 4 & 87.2 & 78.9\end{array}$
Decrease of hot PCA soiuble
$260 \mathrm{~m} \mu$ absorbing material in cells (O.D. $260 \mathrm{~m} \mu$ per $13.7 \mathrm{mg}$ cells)

$\begin{array}{lc} & \text { Aerated } \\ 40.3 & 24.2 \\ 46.1 & 37.6 \\ 52.4 & 43.4\end{array}$

Increase of hot PCA soluble $260 \mathrm{~m} \mu$ absorbing material in suspending medium (O.D. $260 \mathrm{~m} \mu$ of suspending medium obtained from $13.7 \mathrm{mg}$ cells)

$\begin{array}{lc} & \text { Aerated } \\ 43.8 & 44.3 \\ 52.8 & 52.3 \\ 56.8 & 57.8\end{array}$

Washed cells were suspended in $0.25 \mathrm{~m}$ glycine- $\mathrm{NaOH}$ buffer, $\mathrm{pH} 9.55$ to give a cell density of $6.84 \mathrm{mg}$ per ml and incubated at $37^{\circ} \mathrm{C}$ with and without aeration.

the amount of $260 \mathrm{~m} \mu$ absorbing material lost from the cells with that turned up into the suspending medium, which was observed under anaerobic state. This fact indicates that a net synthesis of $260 \mathrm{~m} \mu$ absorbing material occurred during the aerobic incubation.

Effect of Reaction Temperature. The reaction was carried out between 10 and $70^{\circ} \mathrm{C}$; and the excretion was found to occur optimally around 37 to $50^{\circ} \mathrm{C}$. Therefore in the following experiments the incubations were carried out at $37^{\circ} \mathrm{C}$.

Thermostability of Excretion. Thermostability was measured by allowing the suspension of cells to stand at various temperatures for 5 minutes and then incubating in $0.25 \mathrm{M}$ Tris buffer ( $\mathrm{pH} \mathrm{8.0)}$ for 40 minutes at $37^{\circ} \mathrm{C}$. The rate of excretion decreased as the temperature of treatment was raised, and was completely lost by treating the cells at 85 to $100^{\circ} \mathrm{C}$ for 5 minutes.

The behavior at $\mathrm{pH} 9.8$ was the same as that at $\mathrm{pH}$ 8.0.

Effects of Concentration of Buffers and Salts. In the early experiments when buffers of low concentrations were employed the degradation of intracellular nucleic acids was poor, therefore its dependence upon the concentration of buffers was suggested.

Suspensions of intact and disrupted cells were incubated in Tris buffer ( $\mathrm{pH} 8.05)$ of various concentrations and changes in absorb- ance at $260 \mathrm{~m} \mu$ corresponding to RNA, DNA and acid-soluble fraction were examined. The data shown in Fig. 3 indicate that the degradation of RNA either in intact or disrupted cells is greatly dependent upon the concentration of buffer and occurs optimally around $0.25 \mathrm{~m}$. It is also clear that an increase of the absorbance in the acid-soluble fraction

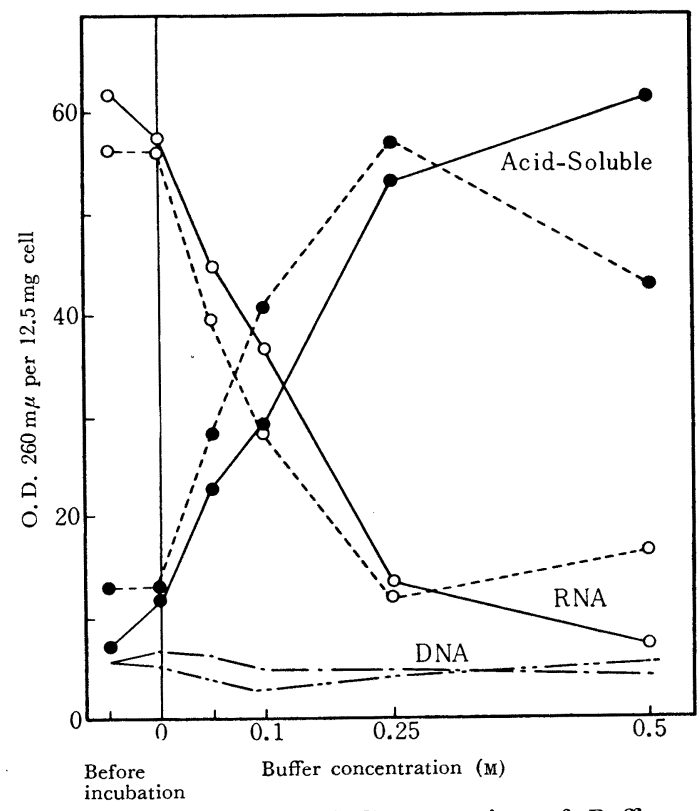

FIG. 3. The Effect of Concentration of Buffer on the Degradation of Nucleic Acids in Intact and Sonicated Cells.

Intact and sonicated cells were incubated in Tris buffer, pH 8.05 of various concentration for 50 minutes at $37^{\circ} \mathrm{C}$. \begin{tabular}{ll} 
Intact cell \\
\hline$\ldots \ldots-$ & Sonicated cell
\end{tabular} 
took place at the expence of the RNA fraction, though little variation was observed in the DNA fraction.

Furthermore, since this behavior was much the same regardless of whether the cells were intact or disrupted, it was suggested that the concentration of buffer does not affect the permeability of the cell membrane but give an influence upon the susceptibility of endogenous RNA to the enzyme (or enzymes) for its degradation, or upon an activation of the enzyme (or enzymes) .

Degradation is also promoted by the addition of various salts such as $\mathrm{NaCl}, \mathrm{KCl}$, ammonium sulfate, and sodium acetate etc., whereas $\mathrm{MgCl}_{2}$ and $\mathrm{CaCl}_{2}$ are inhibitory. Furthermore, other non-ionizing agents such as glucose or urea have no effect.

The effect of concentration of $\mathrm{NaCl}$ was more pronounced than that of Tris buffer as illustrated in Fig. 4, and the excretion occurred optimally at a concentration of around

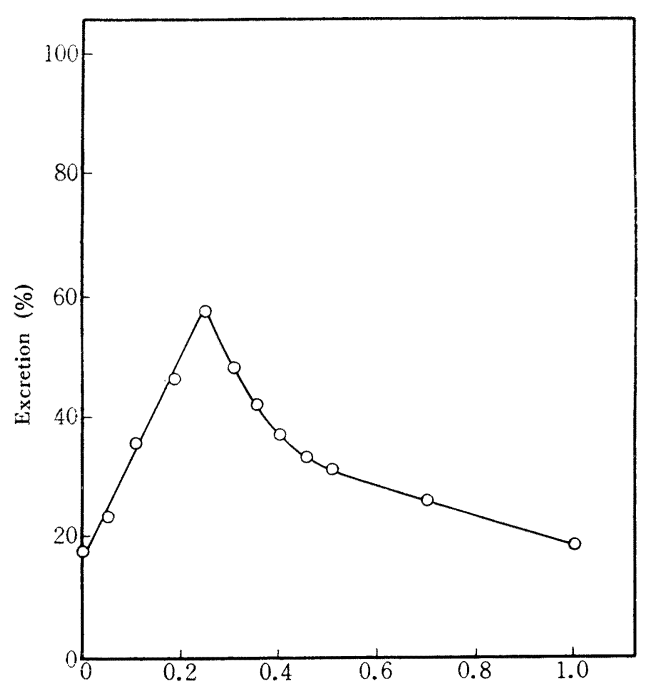

$\mathrm{NaCl}$ concentration (M) in $0.05 \mathrm{M}$ glycine- $\mathrm{NaOH}$ buffer, $\mathrm{pH} 9.4$

FIG. 4. The Effect of Concentration of $\mathrm{NaCl}$ on the Excretion.

Washed cells were suspended in $0.05 \mathrm{M}$ glycine- $\mathrm{NaOH}$ buffer, $\mathrm{pH}$ 9.4 containing various concentrations of $\mathrm{NaCl}$ and incubated for 30 minutes at $37^{\circ} \mathrm{C}$.
TABLE II. THE EFFEct OF VARIOUS METAL IONS ON THE EXCRETION

\begin{tabular}{lcc} 
& \multicolumn{2}{c}{ Concentration in $\mathbf{M}$} \\
& $10^{-2}$ & $10^{-3}$ \\
None (Control) & $100.0 \%$ & $100.0 \%$ \\
$\mathrm{MgSO}_{4}$ & 64.8 & 106.2 \\
$\mathrm{MgCl}_{2}$ & 64.3 & 101.0 \\
$\mathrm{BaCl}_{2}$ & 62.1 & 89.9 \\
$\mathrm{CaCl}_{2}$ & 49.7 & 102.4 \\
$\mathrm{MnCl}_{2}$ & 96.2 & 109.5 \\
$\mathrm{ZnCl}_{2}$ & 92.3 & 100.2 \\
$\mathrm{CuCl}_{2}$ & 60.5 & 84.3 \\
$\mathrm{CoCl}_{2}$ & 99.3 & 102.7 \\
$\mathrm{NiCl}_{2}$ & 104.4 & 98.8 \\
$\mathrm{FeCl}_{3}$ & 75.0 & 99.1 \\
$\mathrm{FeSO}_{4}$ & 75.0 & 85.0 \\
$\mathrm{HgCl}_{2}$ & 36.1 & 37.9
\end{tabular}

Washed cells were suspended in $0.01 \mathrm{~m}$ glycine- $\mathrm{NaOH}$ buffer, $\mathrm{pH}$ 9.4 containing $0.25 \mathrm{M} \mathrm{NaCl}$ and $10^{-2}$ or $10^{-3} \mathrm{M}$ metals and incubated for 40 minutes at $37 \mathrm{C}$. Data are expressed in relative value to control experiment.

\section{$0.25 \mathrm{M}$.}

Effect of Metal Ions. Table II shows the effect of various metal ions on the excretion. Among the metals tested, $\mathrm{Hg}^{++}$shows the greatest inhibition and alkali earth ions generally show inhibitory effects. $\mathrm{Cu}^{++}, \mathrm{Fe}^{++}$ and $\mathrm{Fe}^{+++}$ions also have an inhibitory effect, but $\mathrm{Mn}^{++}$and $\mathrm{Zn}^{++}$have almost no effect.

Effect of Anions and EDTA. As shown in Table III, polybasic anions generally have some stimulatory effect. It is noteworthy that orthophosphate, among the polybasic anions tested, is distinctively stimulatory.

EDTA had an inhibitory effect.

\section{Kinetic Study of the Excretion.}

Washed cells were incubated in buffers and the increase of $260 \mathrm{~m} \mu$ absorbing material in the suspending media and the shifts in various $260 \mathrm{~m} \mu$ absorbing compounds in the cells during the incubation were examined.

Fig. 5 shows that RNA underwent rapid degradation within 60 minutes while DNA retained comparatively constant levels. The absorbance of the acid-soluble fraction in- 
a) $\mathrm{pH} 8.2$

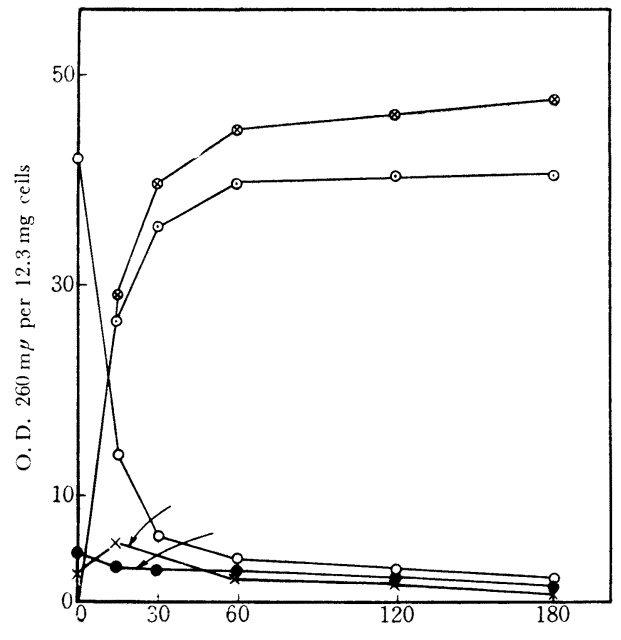

Incubation period $(\min$. b) $\mathrm{pH} 9.8$

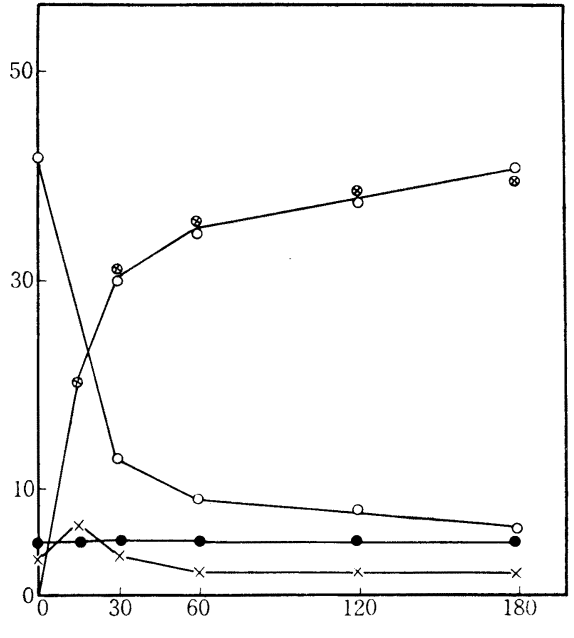

Incubation period $(\min$.

FIG. 5. Shifts in Amounts of RNA, DNA and Acid-Soluble $260 \mathrm{~m} \mu$-Absorbing Compounds During the Incubation of Washed Cells in Buffers.

Washed cells were incubated in a) $0.25 \mathrm{M}$ Tris buffer, $\mathrm{pH} 8.2$ and b) $0.25 \mathrm{M}$ glycine- $\mathrm{NaOH}$ buffer, $\mathrm{pH} 9.8$ at $37^{\circ} \mathrm{C}$.

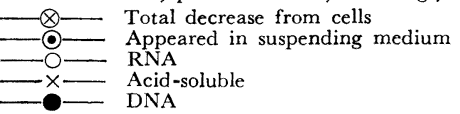

a) $\mathrm{pH} 8.2$

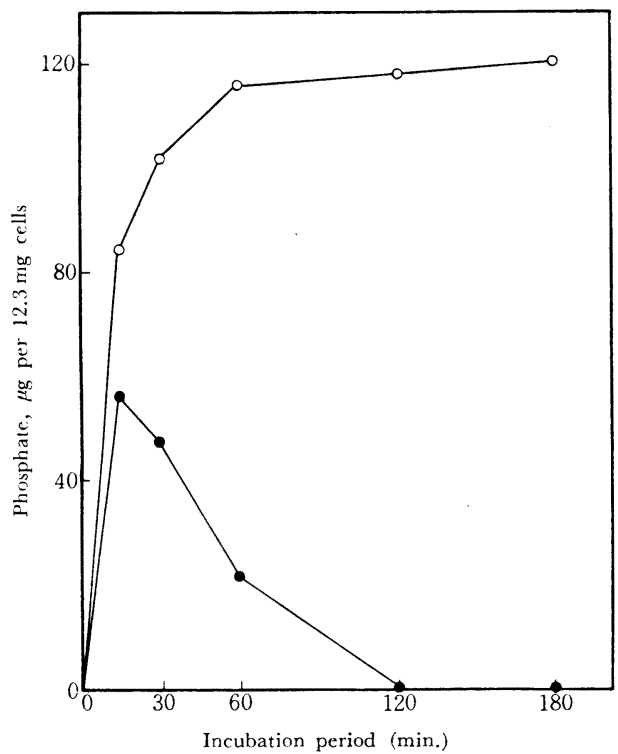

b) $\mathrm{pH} 9.8$

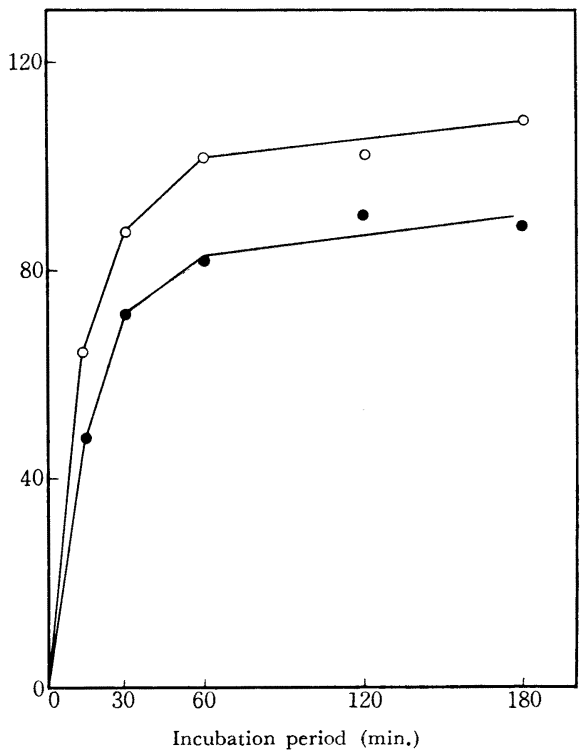

FIG. 6. Relationship Between the Decrease of Intracellular RNA and the Appearance of ExtracelJular 5'-nucleotides.

Data are expressed in phosphate of RNA (RNA-P) and that of 5'-nucleotide (5-P). Experimental conditions are the same as in Fig. 5.

Intracellular RNA degraded (as RNA-P) 
TABle III. THE EFFECT OF VARIOUS ANIONS ON THE EXCRETION

\begin{tabular}{lcc} 
& \multicolumn{2}{c}{ Concentration in M } \\
Anion added & $10^{-2}$ & $10^{-3}$ \\
& $100.0 \%$ & $100.0 \%$ \\
$\mathrm{None}$ (Control) & 99.2 & 100.6 \\
$\mathrm{NaF}$ & 99.6 & 99.0 \\
$\mathrm{KGN}$ & 100.2 & 101.0 \\
$\mathrm{NaN}_{3}$ & 103.8 & 103.3 \\
$\mathrm{Na}_{2} \mathrm{HAsO}_{4}$ & 105.3 & 100.9 \\
$\mathrm{Na}_{-}$citrate & 114.4 & 100.4 \\
$\mathrm{Na}_{2} \mathrm{HPO}_{4}$ & 112.4 & 100.2 \\
$\mathrm{~K}_{2} \mathrm{HPO}_{4}$ & 115.3 & 109.7 \\
$\mathrm{Na}_{4} \mathrm{pyrophosphate}_{\text {EDTA }}$ & 52.4 & 65.2 \\
\end{tabular}

creased a little during the early stage of the incubation and then diminished to some extent towards the later stages.

Since preliminary experiments showed that only $5^{\prime}$-nucleotides were present in the suspending media, increase in the amount of $5^{\prime}$-nucleotides in the suspending media was determined. The relationship between the increase of $5^{\prime}$-nucleotides and the reduction of intracellular RNA during the incubation is indicated in Fig. 6.

When the excretion was carried out at $\mathrm{pH}$ 9.8 , most of the degraded RNA was converted to 5'-nucleotides, while at $\mathrm{pH} 8.2,5^{\prime}$-nucleotides were produced during the early stages, however, 5'-nucleotides once produced were split into smaller fragments later.

Changes in the Viability and the Responce of Gramstaining of Cells during the Excretion.

Relationship between the excretion of nucleotides and the viability of cells was examined. Although the result varied from one experiment to another, number of viable cells was greatly reduced during the excretion. In one experiment, more than $99 \%$ of cells were killed during the incubation of cells for 60 minutes in $0.25 \mathrm{~m}$ glycine- $\mathrm{NaOH}$ buffer, $\mathrm{pH}$ 9.8 and in $0.25 \mathrm{M}$ Tris buffer, $\mathrm{pH}$ 8.0.

It was also observed that this Bacillus lost its responce to Gram-staining as a result of the degradation of endogenous RNA.

Analysis of Nucleotides in the Acid-soluble Fraction of Cells and Excreted into the Suspending Media.

After incubating the cells in $0.25 \mathrm{M}$ glycine$\mathrm{NaOH}$ buffer, pH 9.8 for 30 and 120 minutes at $37^{\circ} \mathrm{C}$, the excreted nucleotides were analysed by ion-exchange chromatography on Dowex-1 $\times$ 8-formate. Analyses of nucleotides in the acid-soluble fraction of cells before the incubation and after incubating the cells for 15 minutes in $0.25 \mathrm{~m}$ glycine- $\mathrm{NaOH}$ buffer, pH 9.8 were also carried out.

The elution pattern from anion exchanger of nucleotides excreted when the cells were incubated in $0.25 \mathrm{~m}$ glycine- $\mathrm{NaOH}$ buffer, $\mathrm{pH}$ 9.8 for 120 minutes at $37^{\circ} \mathrm{C}$ is illustrated in Fig. 7, and the elution pattern of free nucleotides present in the acid-soluble fraction is illustrated in Fig. 8.

The nucleotides excreted at $\mathrm{pH} 9.8$ were mainly composed of ribonucleoside $5^{\prime}$-monophosphates and of traces of nucleoside $5^{\prime}$ diphosphates. The molar proportions of $5^{\prime}$ monophosphates excreted in the suspending buffer were not very different from each other and were composed of almost equal molar amounts of 5'-AMP, 5'-GMP, 5'-CMP and 5'-UMP.

Among the nucleotides in the acid-soluble fraction, 5'-AMP predominated over other nucleotides to a great extent; the amounts of $5^{\prime}$-CMP and 5'-UMP were small. Furthermore, 5'-GMP was negligible in this fraction. The amount of nucleoside 5'-diphosphates was also small except for ADP.

The composition of nucleotides excreted in the suspending medium and remaining in the acid soluble fraction 15 minutes after the start of incubation in $0.25 \mathrm{~m}$ glycine- $\mathrm{NaOH}$ buffer of $\mathrm{pH} 9.8$ was much the same as that of nucleotides excreted 120 minutes after the start of incubation. 


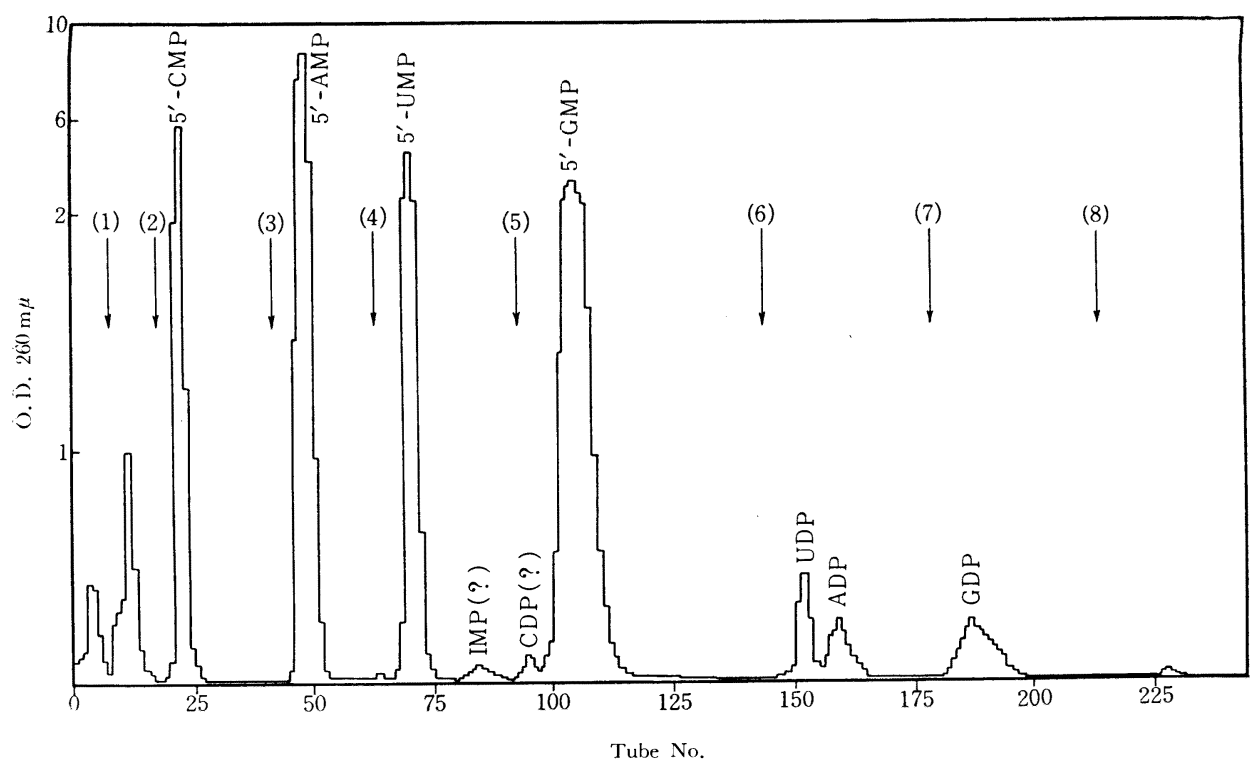

FIG. 7. Separation of Nucleotides Excreted from Washed Cells by an Incubation in $0.25 \mathrm{M}$ glycine$\mathrm{NaOH}$ Buffer, pH 9.8 for $120 \mathrm{~min}$. at $37^{\circ} \mathrm{C}$ by Anion Exchange.

Exchanger: Dowex-1 $\times 8$-formate, $200 \sim 400 \mathrm{mcsh}, 0.79 \mathrm{~cm}^{2} \times 6 \mathrm{~cm}$.

Eluting solution: Formic acid Formic) and sodium formate (Formate) as shown, $0.5 \mathrm{ml} / \mathrm{min}$. Each $10 \mathrm{ml}$ fraction was collected in a tube.

Sorbed material: Nucleotides excreted from washed cell.

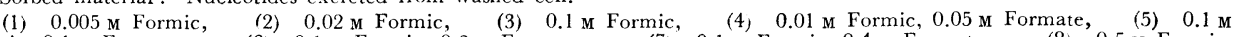
Formic, $0.1 \mathrm{~m}$ Formate, (6) $0.1 \mathrm{M}$ Formic, $0.3 \mathrm{~m}$ Formate, (7) $0.1 \mathrm{~m}$ Formic, $0.4 \mathrm{~m}$ Formate, (8) $0.5 \mathrm{~m}$ Formic, $0.5 \mathrm{~m}$ Formate.

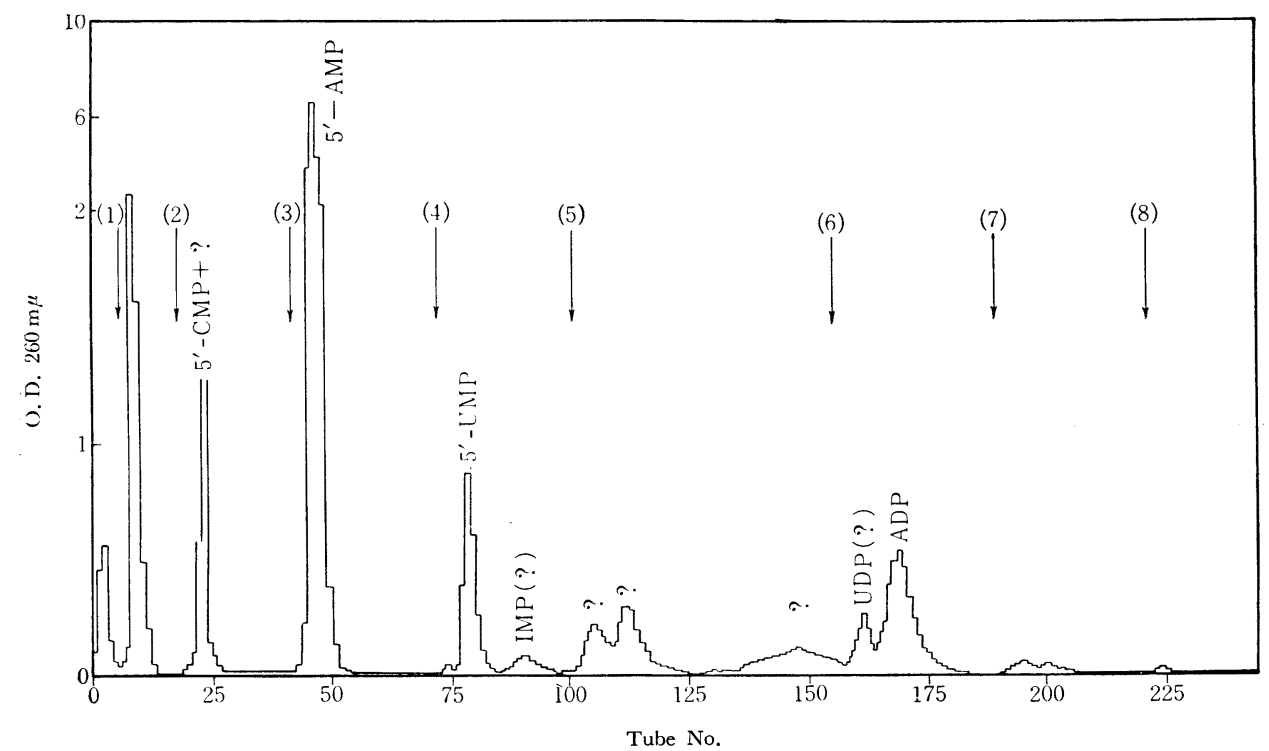

FIG. 8. Separation of Nucleotides in the Acid-Soluble Fraction of Washed Cells by Anion Exchange.

Exchanger and eluting solution: See Fig. 7.

Sorbed material: Nucleotides in the acid-soluble fraction of washed cells.

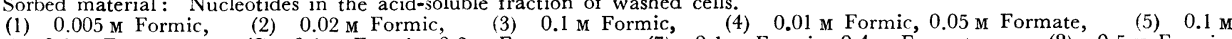
Formic, 0.1 M Formate, $0.5 \mathrm{~m}$ Formate. 
The nucleotides excreted at $\mathrm{pH} 8.2$ (in $0.25 \mathrm{M}$ Tris buffer) were also composed of 5'-AMP, 5'-GMP, 5'-CMP, 5'-UMP and of traces of nucleoside $5^{\prime}$-diphosphates, however, in this case, much more $260 \mathrm{~m} \mu$-absorbing material, presumably bases or nucleosides, was eluted with $0.005 \mathrm{~m}$ formate by ion exchange chromatography.

Variation of the Ability to Degrade Intracellular Nucleic Acids with Conditions and Age of Culture.

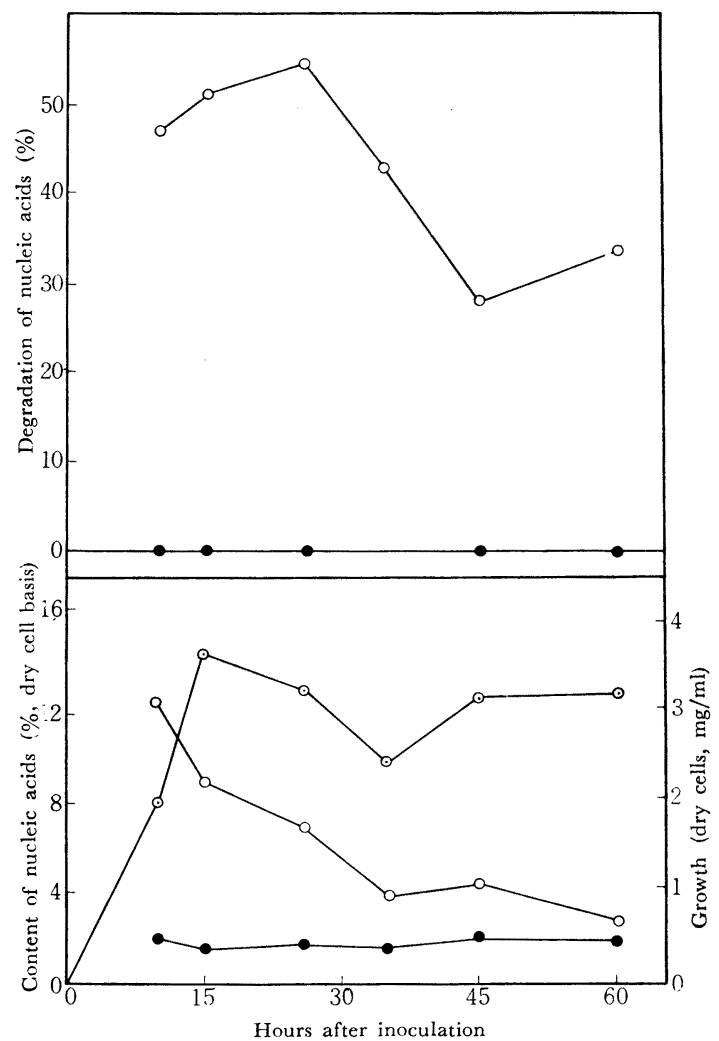

FIG. 10. Shifts in the Ability to Degrade Intracellular Nucleic Acids in Washed Cells According to the Growth Stage.

Bacillus sp. No. 17-5 was cultured in PG-medium and the yicld of dry cells, and content of nucleic acids were estimated (lower half of the figure).

The suspension of washed cells was prepared as in Fig. 9 then mixed with an equal volume of $0.5 \mathrm{M}$ glycine- $\mathrm{NaOH}$ buffer, $\mathrm{pH}$ 10.0 and incubated for 15 minutes at $37^{\circ} \mathrm{C}$. The amounts of RNA and DNA in the cells before and after the incubation in buffer were estimated and the degree of degradation was calculated.

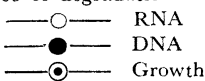

The organism was grown in four media in which it showed different patterns of nucleic acid metabolism. Cells were harvested at various stages of growth and the ability to excrete nucleotides was examined.

In Fig. 9, a) and b) are examples of cultures in which cellular nucleic acids vary in amount to a much greater extent than in c) and d) during the growth.

In cultures a) and b) the ability to excrete nucleotides was most extensive during early stages of growth and diminished towards the latter stages. However, no such variations were detected in c) and d). Moreover, in cultures c) and d) where nucleic acids remained rather at constant levels, this ability was comparatively low.

These facts are considered to show an intimate relationship between the process of the excretion and the metabolism of nucleic acids in vivo.

Here, a question may arise as to whether the excretion is brought about by the reverse reaction of RNA-synthesizing enzymes or by RNA-digesting enzymes. For the purpose of clarifying this point the variation of the ability to degrade endogenous RNA according to the age of the culture was examined.

As shown in Fig. 10, RNA degradation occurred most actively in the stationary phase of growth when cellular RNA was exponentially diminishing. Therefore enzymes participating in this degradation seemed to play a role in the degradation of RNA during growth in vivo.

Evidences for the Identity of Excretion of Nucleotides from Non-proliferating Cells and Accumulation of Nucleotides during Cultivation as the Result of the Same Metabolic Process.

In the previous paper ${ }^{1)}$, it was reported that $5^{\prime}$-nucleotides were accumulated in the culture fluid of this Bacillus and in the present report it has been demonstrated that $5^{\prime}$ - 

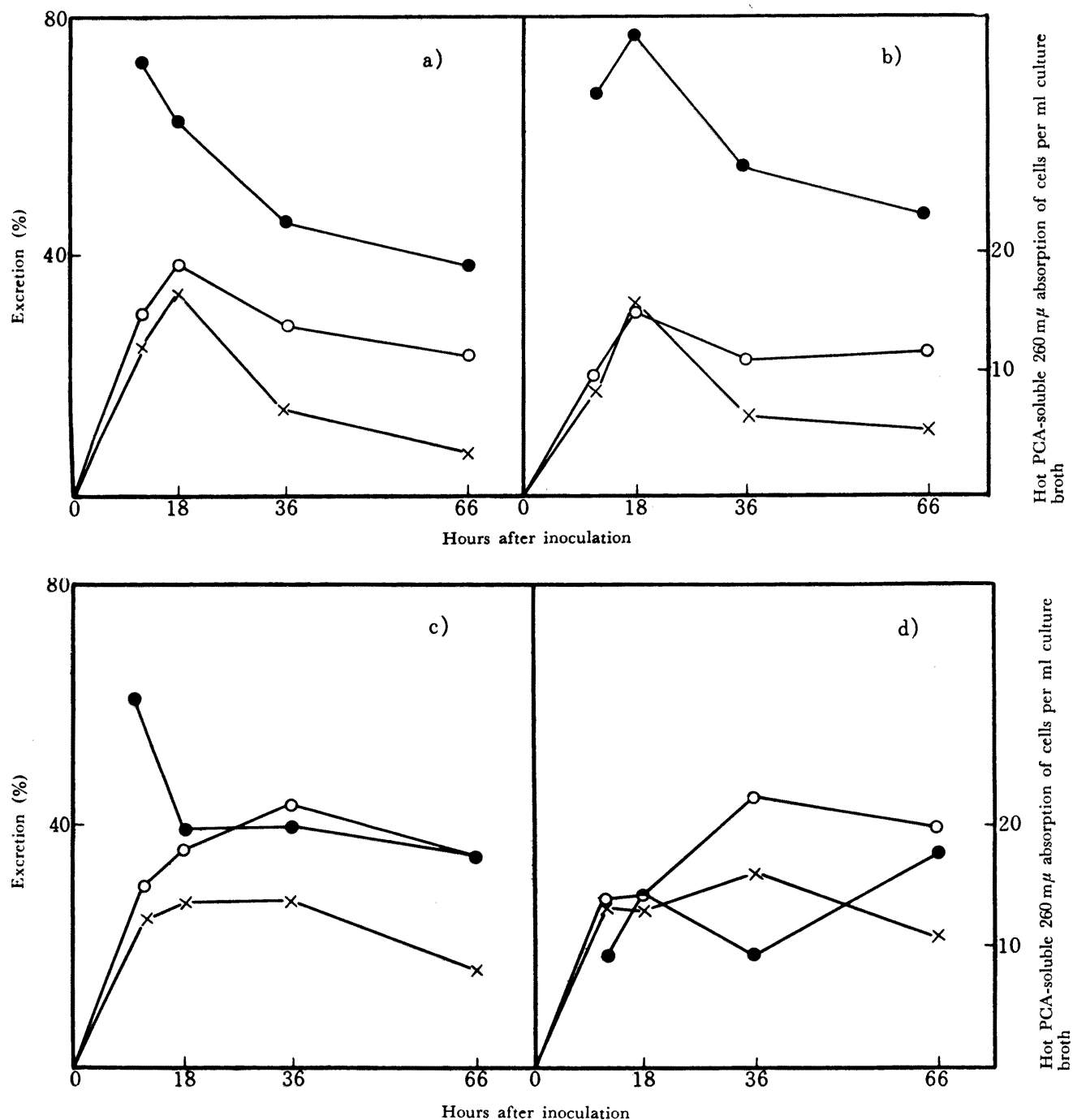

FIG. 9. Variation in the Ability to Degrade Intracellular Nucleic Acids According to Culture Cionditions. Bacillus sp. No. 17-5 was cultivated in a) PG-medium, b) CSL-medium ( $2 \%$ of corn steep liquor was substituted for $1 \%$ of polypeptone in PG-medium), c) G-medium ( $1 \%$ of Casamino acids was substituted for $1 \%$ polypeptone in PG-medium) and d) ME-medium ( $1 \%$ of meat extract was substituted for $1 \%$ polypeptone in PG-medium). Cells were harvested at intervals, washed twice with water and resuspended in distilled water to give a cell density twice as much as that in the culture broth before harvesting the cells. The ability to excretc nucleotides was estimated by adding an equal volume of $0.5 \mathrm{M}$ glycine$\mathrm{NaOH}$ buffer, $\mathrm{pH} 9.4$ to the suspension of washed cells followed by an incubation for 30 minutes at $37^{\circ} \mathrm{C}$, then the degree of excretion was measured as indicated in the text.

Data are expressed as follows: Excretion (\%) as in the text; growth, O. D. $660 \mathrm{~m} \mu$ of the culture broth; and nucleic acids, hot PCA-extractable $260 \mathrm{~m} \mu$-absorbing materials in cells harvested from $1 \mathrm{ml}$ of culture broth.

$$
\begin{aligned}
& -0 \text { Ecretion } \\
& -O-\text { Growth (O. D.) }
\end{aligned}
$$

nucleotides are excreted from washed cells of the same organism when incubated in alka- line salt solutions. Therefore, comparative studies of these two phenomena have been 
made from various points of views.

Comparison of Nucleotides "Accumulated" and "Excreted".

Bacillus sp. No. 17-5 was cultivated in Gmedium 1 ) and fractions "accumulated" and "excreted" were obtained as summarized in Fig. 11. Then nucleotides in these fractions were analysed by ion-exchange chromatography. Chromatograms obtained for both fractions were much the same as that shown in Fig. 7 and the molar ratio of nucleotides in these fractions are indicated in Table IV. The molar ratios of nucleotides in these fractions were very similar.

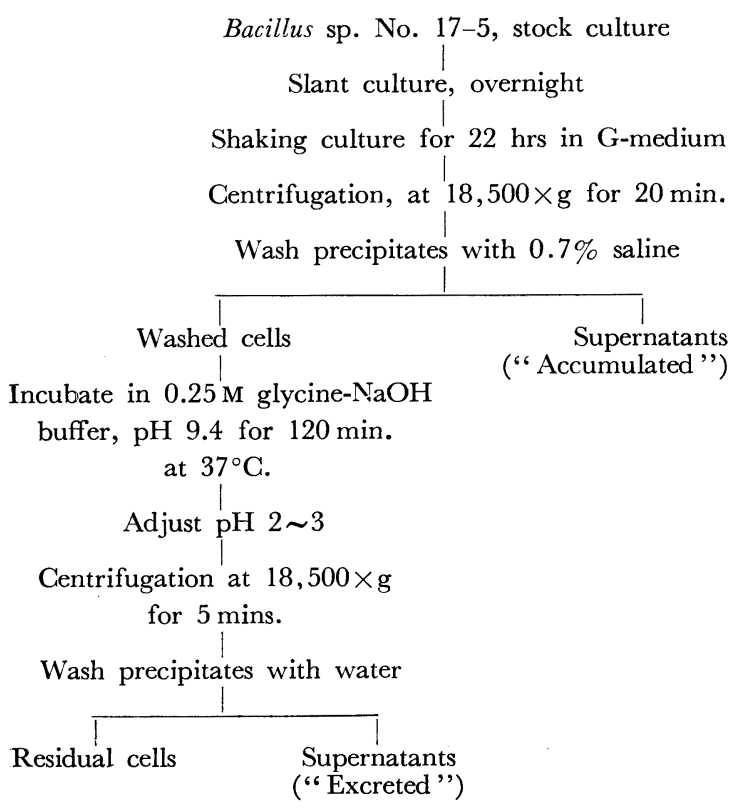

FIG. 11. The Procedures for Obtaining Fractions " Accumulated" and "Excreted".

A comparison of the base composition of these nucleotides with that of nucleotides of intracellular RNA is shown in Table V.

Here again a similarity is observed among base compositions, except that the proportion of adenosine nucleotides was larger than in the former two cases as compared with the
TABle IV. MOlaR RATIOS OF NUCleotides "ACCUMUlated" IN THE GUlture Fluid AND " EXCRETED" FROM THE WASHED CELLS

$\begin{array}{ccc}\text { Nucleotide } & \text { "Accumulated } & \text { "Excreted " } \\ \text { 5'-GMP } & 0.76 & 0.83 \\ \text { 5'-AMP } & 1.00 & 1.00 \\ \text { 5'-UMP } & 0.58 & 0.56 \\ \text { 5'-GMP } & 0.75 & 0.76 \\ \text { GDP (?) } & 0.09 & 0.08 \\ \text { UDP } & 0.20 & 0.20 \\ \text { GDP } & 0.26 & 0.21\end{array}$

Fractions " accumulated" and "excreted" were obtained as shown in Fig. 11, and nucleotides in them were analyzec by ion exchange chromatography. Date are expressed in comparative values against 5'-AMP.

TABLE V. COMPARISON OF COMPOSITIONS OF NUCLEOTIDES "ACCUMULATED" AND "EXCRETED" WITH THAT OF NUClEOTIDES OF INTRACELLULAR RNA

$\begin{array}{lccc}\text { Nucleotide } & \begin{array}{c}\text { "Accumu- " Excre- } \\ \text { lated } \\ \text { ted }\end{array} & \begin{array}{c}\text { Intracel- } \\ \text { lular } \\ \text { RNA }\end{array} \\ \text { Adenosine nucleotide } & 1.18 & 1.10 & 0.99 \\ \text { Guanosine nucleotide* } & 1.20 & 1.07 & 1.18 \\ \text { Cytidine nucleotide** } & 1.00 & 1.00 & 1.00 \\ \text { Uridine nucleotide*** } & 0.92 & 0.84 & 0.82 \\ \text { *Sum of 5'-GMP and GDP, **Sum of 5'-CMP and CDP(?), and } \\ \text { ***Sum of 5'-UMP and UDP. } \\ \text { Composition of nucleotides of intracellular RNA was estimated as } \\ \text { mentioned in the previous report1). Data are expressed in com- } \\ \text { parative values based on cytidine nucleotide. }\end{array}$

base composition of intracellular RNA. However, this fact may be explainable on the basis that adenosine nucleotides predominate in the acid-soluble fraction of cells.

Effects of Phosphate, $\mathrm{NaCl}$ and $\mathrm{CaCO}_{3}$ on the "accumulation" of Nucleotides during Cultivation.

If the accumulation of nucleotides during cultivation was brought about by the same metabolic system as the excretion of nucleotides from washed cells, factors which stimulate or inhibit the excretion would be expected to affect the accumulation in a similar manner. Therefore, three factors which had some influences on the excretion were tested for their behaviors on the accumulation of nucleotides in the growth medium.

Potassium phosphate buffer, $\mathrm{pH}$ 7.0, was 
added to G-medium ${ }^{1)}$ from which phosphate had been excluded, to final concentrations of $0.055 \mathrm{M}, 0.0275 \mathrm{M}$ and $0.01375 \mathrm{M}$; and the organism was cultivated in these media. The accumulation of $260 \mathrm{~m} \mu$ absorbing material in the culture fluid increased with the increased concentration of phosphate, whereas intracellular nucleic acids remained at com-

Table Vi. The Degradation of Intracellular Nucleic Acids in Washed Gells AND THE Formation OF 5'-NUClEOTIDES AS A RESUlt OF THE DEGRADATION BY VARIOUS BACTERIAL STRAINS

\begin{tabular}{|c|c|c|c|c|c|}
\hline \multirow[b]{2}{*}{ Bacterial strain } & \multirow[b]{2}{*}{ edium* } & \multicolumn{2}{|c|}{$\begin{array}{c}\text { Incubation in } 0.25 \mathrm{M} \text { tris } \\
\text { buffer, } \mathrm{pH} 8.0\end{array}$} & \multicolumn{2}{|c|}{$\begin{array}{c}\text { Incubation in } 0.25 \mathrm{M} \\
\text { glycine-NaOH buffer pH } 9.4\end{array}$} \\
\hline & & $\begin{array}{l}\text { Degree of } \\
\text { excretion }\end{array}$ & $\begin{array}{c}\text { Formation } \\
\text { of } \\
5^{\prime} \text {-nucleotides }\end{array}$ & $\begin{array}{l}\text { Degree of } \\
\text { excretion }\end{array}$ & $\begin{array}{c}\begin{array}{c}\text { Formation } \\
\text { of }\end{array} \\
5^{\prime} \text {-nucleotides }\end{array}$ \\
\hline Bacillus sp. No. 17-5 & A & $H(86.3)^{* *}$ & \#(58.0)*** & 卅(89.4)** & \#(63.4)*** \\
\hline Aerobacter aerogenes & A & $H(61.5)$ & trace & H(41.0) & trace \\
\hline Azotomonas sp. & A & $+(32.1)$ & trace & H(60.1) & \#(53.6) \\
\hline Bacillus megaterium & A & H(89.2) & trace & \#(90.3) & $H(22.2)$ \\
\hline B. cereus & A & $H(61.2)$ & trace & \#(86.0) & $H(24.2)$ \\
\hline B. cereus var. mycoides & B & W(79.1) & none & 世(77.7) & + \\
\hline B. polymyxa & $\mathrm{S}$ & 世 & H & H & 卅 \\
\hline B. pumilus & G B & H & H & H & none \\
\hline B. subtilis & $\mathrm{S}$ & 世 & none & H & + \\
\hline Bacterium mycoides & G B & WH & m & H & + \\
\hline Corynebacterium sepedonicum & $\mathrm{S}$ & \#(81.4) & none & \#(80.1) & none \\
\hline Escherichia coli & A & $H(63.3)$ & trace & H(41.0) & trace \\
\hline Micrococcus flavus & Mix. & $+(15.5)$ & none & $+(10.7)$ & none \\
\hline M. lysodeikticus & A & $+(21.8)$ & trace & $+(11.3)$ & W(138.0) \\
\hline M. pyogenes var. albus & $\mathrm{S}$ & $H(35.1)$ & trace & H(42.3) & trace \\
\hline M. pyogenes var. aureus & $\mathrm{S}$ & $H(36.9)$ & none & $+(30.0)$ & none \\
\hline Pseudomonas aeruginosa & A & \#(70.5) & $H(24.8)$ & $H(65.8)$ & W(51.5) \\
\hline Ps. coronafaciens & Mix. & m & H & W & H \\
\hline Ps. fragi & A & $H(78.8)$ & $H(21.8)$ & 世(86.6) & \#(45.5) \\
\hline Ps. graveolens & A & $H(63.5)$ & $+(7.4)$ & $H(65.4)$ & 世(62.7) \\
\hline Ps. riboflavianus & A & $+(30.9)$ & trace & $+(33.8)$ & trace \\
\hline Ps. striafaciens & Y B & H & H & \# & H \\
\hline Sarcina albido & A & $+(27.7)$ & none & $+(26.2)$ & trace \\
\hline Sarcina lutea & A & $+(16.2)$ & trace & $+(17.2)$ & m \\
\hline Serratia marescens & A & $H(48.5)$ & trace & $H(55.8)$ & trace \\
\hline Serratia polithicum & $\mathrm{A}$ & $+(20.1)$ & trace & $+(23.0)$ & H(111.0) \\
\hline Proteus vulgaris & $\mathrm{B}$ & H & none & \# & + \\
\hline Vibrio percolans & A & \# & none & H & $H$ \\
\hline
\end{tabular}

Various type cultures of bacteria were cultured in media indicated in the Table for 20 to 24 hours at $28^{\circ} \mathrm{C}$, with shakıng. The cells were harvested by centrifugation, washed twice with water and resuspended in water to give a cell density twice as much as that in the culture broth beforc harvest of cells. This cell-suspension was mixed with the same volume of $0.5 \mathrm{~m}$ Tris buffer, $\mathrm{pH} 8.0$ and $0.5 \mathrm{M}$ glycine- $\mathrm{NaOH}$ buffer, $\mathrm{pH} 9.4$ and incubated for 2 hours at $37^{\circ} \mathrm{C}$, and the degree of the excretion was measured as in the text.

* Media A, B, S, GB, YB and Mix. are as follows: A, acetic acid was used in place of glycerol in G-medium and neutralized with $\mathrm{NaOH} ; \mathrm{B}$, acetic acid in $\mathrm{A}$ was neutralized with ammonium hydroxide; $\mathrm{S}$, $\mathrm{S}$-medium as desrribed in the previous paper ${ }^{1)}$; GB, nutrient broth containing $1 \%$ of glucose; YB, yeast extract was used in place of meat extract in GB; Mix., yeast extract was added to GB to $0.5 \%$.

** Degree of excretion (\%), calculated as described in the text.

+ , the degrce was less than 35\%; H, the degree was between 35 to $70 \%$; $\#$, the degree was more than $70 \%$.

*** Yield of 5'-nucleotide (calculated from the amount of $5^{\prime}-\mathrm{P}$ ) per degraded nucleic acids.

+ , the yicld was less than $15 \%$; $H$, the degree was between 15 to $40 \%$; $\#$, the degree was more $\operatorname{tnan} 40 \%$. 
paratively constant levels.

When $\mathrm{NaCl}$ was added to G-medium to a final concentration of $0.25 \mathrm{M}$, the accumulation was elevated to a great extent, especially during the early stages of growth.

When $\mathrm{CaCO}_{3}$ was added to G-medium to a final concentration of $0.05 \mathrm{M}$, the accumulation of $260 \mathrm{~m} \mu$ absorbing material in the culture fluid was extremely inhibited and nucleic acids became extraordinarily accumulated in the cells owing to the suppression of endogenous nucleic acids degradation by the metal.

These three factors affected the accumulation of nucleotides during the cultivation stimulatory or inhibitory as well as on the excretion of nucleotides from washed cells.

\section{Distribution of Homologous Phenomenon in Other Bacteria}

From the above mentioned results, the degradation of endogenous RNA evoked by incubating washed cells of a Bacillus in alkaline buffer or salt solutions is suggested to be intimately connected with the degradation of RNA during growth. Moreover, since the degradation of RNA is generally observed during the cultivation of various microorganisms $^{3 \sim 7)}$, this type of degradation could be expected to occur in other micro-organisms. Therefore, a variety of bacteria were tested for their ability to degrade their endogenous nucleic acids.

As depicted in Table VI, most of Grampositive or -negative rods carried out an extensive degradation of endogenous nucleic acids and some of them produce $5^{\prime}$-nucleotides in the suspensing media. On the other hand, cocci generally showed lesser degrees of excretion as compared with rods, however, 5'-

\footnotetext{
3) H.B. Levy, E.T. Skutch and A.L. Schade, Arch. Biochem., 24, 199, 206 (1949).

4) P.C. Caldwell, E.L. Mackor and Sir C. Hinshelwood, J. Chem. Soc., 1950, 3151 .

5) H.E. Wade, J. Gen. Microbiol., 7, 24 (1952).

6) B.J. Katchman and W.O. Fetty, J. Bacteriol., 69, 607 (1955).

7) J. Brachet, "The Nucleic Acids", Vol. II, Ed. E. Chargaff and J.N. Davidson, Academic Press, New York, 1955, p. 475.
}

nucleotides were formed by some cocci.

It may therefore be concluded that this kind of degradation of intracellular nucleic acids when washed cells are incubated in alkaline buffers is a common phenomenon in many bacteria.

\section{DISCUSSION}

Degradation of Endogenous Nucleic Acids and Formation of $5^{\prime}$-Nucleotides. Our present work has demonstrated that $5^{\prime}$-nucleotides are excreted from washed cells of a Bacillus when incubated in alkaline salt or buffer solutions. These nucleotides were shown to originate from endogenous RNA.

Although many investigations have been made on the degradation of RNA in cells of various microorganisms either during the growth of them or during incubation in buffers, there have been few indications that $5^{\prime}$ nucleotides are formed.

In the past, Newton $(1957)^{8)}$, Holden $(1958)^{9)}$, Cohn et al. (1958) ${ }^{10)}$ and Herbst and Doctor (1959) ${ }^{11}$ studied the degradation of nucleic acids in Pseudomonas aeruginosa, Lactobacillus arabinosus, Rickettsia mooseri and on Hemophilus influenzae, respectively. However, nothing was mentioned about the breakdown products. Higuchi and Uemura (1959) ${ }^{12)}$ showed that Saccharomyces cerevisiae excreted mono-, oligo-, and polynucleotides possessing terminal phosphate in the $3^{\prime}$ position, when the cells were incubated in slightly acid buffer in the presence of chelating agents such as citrate or EDTA. Stephenson and Moyle (1949) ${ }^{13}$ ) found that mono-nucleotides were excreted by $E$. coli when incubated in carbonate buffer, $\mathrm{pH}$ 7.4, in the presence about $0.2 \mathrm{~m}$ of sodium lactate,

\footnotetext{
8, B.A. Newton, J. Gen. Microbiol., 9, 54 (1953)

9. J.T. Holden, Biochim. Biophys. Acta, 29, 667 (1958).

10) Z.A. Cohn, F.E. Hahn, W. Ceglowski and F.M. Bozeman, Science, 127, 282 (1958).

11) E.J. Herbst and B.P. Doctor, J. Biol. Chem., 234, 1497 (1959).

12) M. Higuchi and T. Uemura, J. Agr. Chem. Soc. (Japan), 33, $304,821,826$ (1959).

13) M. Stephenson and J.M. Moyle, Biochem. J., 45, vii (1949).
} 
$\mathrm{NaCl}$ or $\mathrm{KCl}$, and this work somewhat resembles our present investigation. However, no data were given concerning the kind of isomer these nucleotides might be.

The formation of $5^{\prime}$-nucleotides in the culture fluid of streptomycin inhibited cultures of $E$. coli was reported by Davis and his collaborators $(1959,1960)^{14 \sim 16)}$ and Rosano et al. $(1960)^{17)}$. Whereas the former investigators clearly demonstrated that these nucleotides were not degradation products but formed do novo, the latter did not give any conclusion, however, they suggested the possibility that the accumulated nucleotides originated from intracellular RNA.

The work of Wade $(1961)^{18)}$, although published after the completion of the present investigation, is similar to ours. He studied the autodegradation of ribonucleoprotein of $E$. coli and found a route through which RNA is degraded into $5^{\prime}$-nucleotides at alkaline $\mathrm{pH}$.

The degradation of endogenous RNA and the consequent excretion of $5^{\prime}$-nucleotides from washed cells of a Bacillus examined in the present work occurred optimally in an alkaline $\mathrm{pH}$ region. This excretion greatly depended upon the concentration of salt or buffer in the incubation medium. This dependence is considered to be an influence of these dilute salts or buffers upon the susceptibility of RNA to digestive enzymes or upon the enzyme activity itself. Stephenson and Moyle $(1949)^{13)}$ reported similar effects of salts on the degradation of RNA in E. coli. Apart from this there are also a number of indications that the degradation of RNA or polynucleotides by ribonuclease or other enzymes depends upon the presence of a variety

\footnotetext{
14) H. Roth, H. Amos and B.D. Davis, Bacteriol. Proc., 1959, 131. 15) N. Anand and B.D. Davis, Nature, 185, 22 (1960).

16) H. Roth, H. Amos and B.D. Davis, Biochim. Biophys. Acta, 37, $398(1960)$.

17) C.L. Rosano, R.A. Peabody and C. Hurwitz, Biochim. Biophys. Acta, 37, 380 (1960).

18) H.E. Wade, Biochem. J., 78, 457 (1961).
}

of salts; Fellig and Wiley (1960) ${ }^{19)}$ reported that the ribonuclease of Euglena gracilis was activated by $0.5 \mathrm{~m} \mathrm{NaCl}$, Spahr and Hollingworth $(1961)^{20)}$ showed that the ribonuclease in ribonucleoprotein of $E$. coli was activated by $0.25 \mathrm{M} \mathrm{NaCl}$ and Hendley and Beers (1961) ${ }^{21)}$ observed an extensive acceleration of phosphorolysis of polyadenylic acid upon increasing the ionic strength of the incubation medium.

Furthermore, it has been known that the ribosomes of $E$. coli and other organisms contain a latent ribonuclease which is activated by the separation of the RNA from the protein moiety by means of an agent such as urea $^{22 \sim 28)}$.

The promotion of the degradation of RNA by salts or buffers in a Bacillus observed by us may be attributed to an influence of salts or buffers upon the physicochemical properties of ribosome or ribosomal RNA bringing about a higher sensitivity of the digestive enzymes, since as will be described in the forthcoming paper ${ }^{29)}$, RNA in heat denaturated ribosomes of this organism was rapidly degraded by its own intracellular enzyme system even at low buffer concentrations, whereas RNA in intact ribosomes was degraded only at higher concentrations.

Several polybasic anions more or less promoted excretion and alkali earth metals at relatively low concentrations $(10 \mathrm{~mm})$ inhibit

19) J. Fellig and C.E. Wiley, Science, 132, 1835 (1960).

20) P.F. Spahr and B.R. Hollingworth, J. Biol. Chem., 236, 823

(1961) D.D. Hendley and R.F. Beers, Jr., J. Biol. Chem., 236, 2050 (1961).

22) D. Elson, Biochim. Biophys. Acta, 27, 216 (1958;.

23) D. Elson, Biochim. Biophys. Acta, 36, 372 1959).

24) E.T. Bolton, R.J. Britten, D.B. Cowie, B.J. McCarthy, K. MaQuillen and R.B. Roberts, Carnegie Institution of Washington, Annual Report, 1959, p. 259.

25) Y. Otaka and K. Uchida, Proceedings for the Meeting of 9th Symposium on Nucleic Acids, and Ist Symposium on Microbial Genetics, February, 1961 Tokyo).

26) P. Siekewitz and G.E. Palade, J. Biophys. Biochem. Cytol., 4, 309 (1958).

27) Y. Tashiro, J. Biochem. (Japan), 45, 937 (1958).

28) S.R. Dickman and K.M. Trupin, Biochim. Biophys. Acta, 30, 200 (1958).

29) A. Imada, N. Nakao and K. Ogata, Agr. Biol. Chem., 26, 611 (1962) 
excretion. This fact seems to show that effective anions may promote the degradation by removal of protective cations as reported by Holden (1958) in L. arabinosus ${ }^{8)}$. However, EDTA was inhibitory and a metal requirement was therefore expected.

It is noteworthy that phosphates are the most effective anion, suggesting that phosphates may act in a different way than other anions.

Kinetic studies revealed that the excretion of $5^{\prime}$-nucleotides was almost complete within one hour, when 70 to $90 \%$ of the RNA initially present in the cells had been consumed, whereas DNA was little degraded in the same interval. Therefore, the enzyme concerned with the excretion is presumed to be very specific for RNA.

Nucleotides excreted into the suspending media consisted maily of ribonucleoside $5^{\prime}$ monophosphates and of traces of ribonucleoside 5'-diphosphates. However, no 2'- or 3'isomers were found. These diphosphates were not present in the acid-soluble fraction of this organism and only appeared upon incubating the cells in buffers, therefore they were assumed to be degradation products.

The formation of ribonucleoside $5^{\prime}$-diphosphates suggests to us the participation of polynucleotide phosphorylase in RNA digestion. Such a concept is further supported by the stimulatory effect of phosphate and the inhibitory effect of EDTA. In the forthcoming paper, the existence of polynucleotide phosphorylase will be examined.

"Accumulation" of Nucleotides during Cultivation and "Excretion" of Nucleotides from Washed Cells.
The mechanism of the accumulation of nucleotides during cultivation of this organism in growth media seemed identical with that of the excretion of $5^{\prime}$-nucleotides during the incubation of washed cells in buffers from the following reasons: the composition of nucleotides formed in both processes resembled each other and also resembled that of nucleotides in intracellular RNA; and the addition of phosphate, and $\mathrm{NaCl}$ promoted both processes but $\mathrm{Ca}^{++}$inhibited both processes.

Biological Significance of the Phenomenon. The ability to degrade endogenous RNA varied according to conditions or to the age of the culture. Generally, the ability was strong in stationary phase cells which were actively degrading endogenous RNA. Furthermore, when cells were grown in media in which the content of nucleic acids did not vary to a great extent throughout the growth cycle, the activity remained relatively low.

Thus the degradation of endogenous RNA studied in the present paper is intimately related to the catabolism of RNA in vivo in this Bacillus.

Furthermore, this type of degradation, with the occasional consequent formation of $5^{\prime}$. nucleotides occurred in a variety of bacteria, suggesting that it might be an essential process for the metabolism of RNA, therefore for the growth of bacteria.

Acknowledgement. We should like to express our thanks to Drs. S. Kuwada, K. Sato, S. Tatsuoka for their interests in this work and for their encouragements. We also thank Dr. E. Ohmura for his helpful advice during the course of this investigation. 